\title{
ANALISIS PENERAPAN AKUNTANSI LINGKUNGAN PADA RUMAH SAKIT UMUM HAJI SURABAYA DALAM PANDANGAN MAQASHID SYARIAH
}

\author{
Susi Susanti*, Ahmad Baehaqi, Muhammad Asmeldi Firman \\ Sekolah Tinggi Ekonomi Islam SEBI \\ Jl. Raya Bojongsari No. 63, Depok, Jawa Barat 16517 \\ Email: soesusanti56@gmail.com*
}

\begin{abstract}
This study aims to analyze the application of environmental accounting in the Hajj public hospital in the view of maqashid sharia. The hospital which is the object of this research is RSU Haji Surabaya. This study uses a qualitative analysis method and a literature study approach. Sources of data use secondary data, namely in the form of journal literature and the official hospital website. Based on the research results, it is known that RSU Haji has implemented environmental accounting by issuing environmental costs. Costs incurred related to waste management at RSU Haji Surabaya consist of water costs, decoration service fees, cleaning service fees, waste management costs, building and building maintenance costs and road maintenance, irrigation, installation and network costs. The implication of environmental accounting at RSU Haji Surabaya is an implementation of objectives in maqashid sharia. Expenditures for maintaining the environment and buildings and treating hospital waste as a form of implementation of the goals of hifzdul nafs or protecting the soul and hifdzul bi'ah or protecting the environment, where the hospital prioritizes the comfort of patients and also the community around the hospital. In addition, the costs for providing facilities and infrastructure related to the provision of prayer rooms, wudlu places and separate bathrooms are the implementation of hifdzul dein or guarding religion.
\end{abstract}

Keywords: Environmental Accounting, Waste, Hospital, Maqashid Syariah

\begin{abstract}
ABSTRAK
Penelitian ini bertujuan untuk menganalisis penerapan akuntansi lingkungan di rumah sakit umum haji dalam pandangan maqashid syariah. Rumah sakit yang menjadi objek penelitian ini adalah RSU Haji Surabaya. Penelitian ini menggunakan metode analisis kualitatif dan pendekatan studi literatur. Sumber data menggunakan data sekunder yaitu berupa literatur jurnal dan website resmi rumah sakit. Berdasarkan hasil penelitian diketahui bahwa RSU Haji telah menerapkan akuntansi lingkungan dengan mengeluarkan biaya-biaya lingkungan. Biaya yang dikeluarkan terkait pengelolaan limbah di RSU Haji Surabaya terdiri dari biaya air, biaya jasa dekorasi, biaya jasa kebersihan, biaya pengelolaan sampah, biaya pemeliharaan gedung dan gedung serta pemeliharaan jalan, irigasi, instalasi dan biaya jaringan. Penerapan akuntansi lingkungan di RSU Haji Surabaya merupakan implementasi tujuan maqashid syariah. Pengeluaran untuk memelihara lingkungan dan bangunan serta mengolah limbah rumah sakit sebagai wujud pelaksanaan tujuan hifzdul nafs atau menjaga jiwa dan hifdzul bi'ah atau menjaga lingkungan, di mana rumah sakit mengutamakan
\end{abstract}


kenyamanan pasien dan juga masyarakat sekitar RSU. Selain itu, biaya penyediaan sarana dan prasarana seperti mushola, tempat wudlu dan kamar mandi terpisah merupakan pelaksanaan hifdzul diin atau menjaga agama.

Kata kunci: Akuntansi Lingkungan, Sampah, Rumah Sakit, Maqasid Syariah

\section{PENDAHULUAN}

Pencemaran lingkungan yang terjadi di Indonesia sudah mencapai pada tahap yang menghawatirkan. Lingkungan semakin tercemari oleh limbah yang dihasilkan dari aktivitas industri baik itu pabrik, rumah sakit, dan hotel. Hal ini kemudian menjadi dorongan pembentukan Asosiasi Pengendali Pencemaran Lingkungan (APPLI) pada tanggal 10 Desember 2008. Esensi sebuah industri adalah hubungan timbal balik dari lingkungan masyarakat kepada industri dalam hal ini tidak dapat dipisahkan (Irawan, 2016).

Sebuah industri dikatakan memiliki kepedulian terhadap permasalahan lingkungan, jika suatu perusahaan memiliki perhatian dan mampu menyelesaikan persoalan yang terjadi. Salah satunya adalah dukungan terhadap lingkungan. Seringkali usaha meningkatkan produktivitas dan efisiensi mengakibatkan penurunan kualitas lingkungan, berupa pencemaran udara, air, dan pengurangan fungsi tanah. Hal tersebut menimbulkan dampak yang sangat buruk pada lingkungan, bahkan berakibat rusaknya alam (Sakdiyah, 2017).

Faktor yang menyebabkan kerusakan alam itu sendiri terbagi menjadi dua, yakni akibat peristiwa alam dan akibat ulah manusia. Faktor kerusakan lingkungan disebabkan oleh peristiwa alam seperti halnya letusan gunung berapi, longsor, gempa bumi, banjir bandang dan kemarau panjang. Sedangkan kerusakan alam yang disebabkan oleh ulah manusia diantaranya adalah degradasi alam dan pencemaran lingkungan (Ikhsan, 2008).

Kerusakan alam dapat diminimalisir dengan menghindari terjadinya degradasi dan pencemaran lingkungan oleh manusia. Jika manusia tidak melakukan hal- hal yang bersifat merusak, maka alam akan terjaga kelestarian nya. Saat ini telah muncul kesadaran dan upaya dari berbagai bidang untuk menanggulangi dan menemukan solusi atas permasalahan lingkungan ini, dan salah satunya adalah dari sisi akuntansi, yaitu akuntansi lingkungan (Burhany, 2014).

Akuntansi Lingkungan sendiri mulai berkembang dan berperan dalam meningkatkan nilai perusahaan. Banyak penelitian yang dilakukan berkaitan dengan tema akuntansi lingkungan. Penelitian ini umumnya dilakukan di negara maju, sedangkan untuk negara berkembang khususnya Indonesia sudah mulai ditingkatkan akhir-akhir ini. Penelitian yang dilakukan di negara maju contohnya Australia, mengenai penyediaan informasi lingkungan bagi perusahaan dan pengungkapan informasi lingkungan dalam laporan tahunan pemerintah pusat yang berperan dalam operasi perusahaan (Utama, 2016).

Sebagaimana diketahui akuntansi lingkungan sangat dibutuhkan oleh setiap perusahaan, dikarenakan penggunaan konsep akuntansi lingkungan bagi perusahaan dapat mendorong kemampuan untuk meminimalisasi 
persoalan- persoalan lingkungan yang dihadapinya. Banyak industri besar dan jasa yang kini menerapkan akuntansi lingkungan, agar dapat meningkatkan efisiensi pengelolaan lingkungan dengan melakukan penilaian kegiatan lingkungan dari sudut pandang biaya dan manfaat atau efek (Windasari \& Herumurti, 2010).

Tidak hanya industri pabrik atau pertambangan yang memiliki peran merusak lingkungan, namun organisasi nirlaba/nonlaba juga berpeluang merusak lingkungan seperti rumah sakit. Sebuah rumah sakit harus mempunyai kemampuan pelayanan medis dan harus melakukan pengelolaan limbah yang dihasilkan. Konsep rumah sakit yang berwawasan lingkungan lebih diarahkan pada penggunaan air yang efektif dan efisien, penggunaan energi listrik yang efisien, serta pengelolaan limbah cair yang berwawasan lingkungan (Noviani \& Aminah, 2014).

Setiap rumah sakit baik itu rumah sakit islam ataupun rumah sakit umum akan mengedepankan unsur ketuhanan. Dimana rumah sakit meimiliki tanggung jawab untuk menjaga keseimbangan antar item didalamnya dan memperlakukannya dengan sama. Lako (2004) menjelaskan sebuah pengertian mengenai teori triple bottom line bahwa pelaporan yang menyajikan informasi tentang kinerja ekonomi (profit), lingkungan (planet), dan sosial (people) dari suatu entitas perusahaan. Tujuannya agar stakeholder bisa mendapat informasi yang lebih komprehensif untuk menilai kinerja, risiko, dan prospek bisnis, serta kelangsungan hidup suatu perusahaan.

Hamidi \& Worthington, (2018) mengembangkan teori triple bottom ini menjadi 4P, yakni profit (kinerja ekonomi), planet (lingkungan), people (sosial) dan prophet (kenabian). Hal ini sesuai dengan prinsip yang dimiliki oleh rumah sakit, yaitu berpedoman pada nilai-nilai ketuhanan. Beberapa rumah sakit yang berlabel Islam menerapkan system tersebut, salah satunya yaitu rumah sakit Islam Surakarta (Sunawi, 2012). Dan dari segi sudut pandang hukum Islam sendiri bahwa nilai-nilai etis yang mampu menyadarkan manusia untuk selalu ramah lingkungan adalah surah alRum:41. Allah mempermaklumkan bahwa manusia adalah makhluk yang paling bertanggungjawab bila terjadi kerusakan dibumi. Masalah kerusakan lingkungan ini juga dijelaskan dalam Q.S: Ar-Rum (30:41)

Artinya: "Telah nampak kerusakan di darat dan di laut disebabkan karena perbuatan tangan manusia, Allah menghendaki agar mereka merasakan sebagian dari (akibat) perbuatan mereka, agar mereka kembali (ke jalan yang benar)."

Kedudukan manusia di muka bumi ini sebagai khalifah Allah, yang diberi tugas untuk memelihara dan melestarikan alam, mengambil manfaat, serta mengelola kekayaan alamnya sehingga terwujud kedamaian dan kesejahteraan manusia. Dalam kegiatan apapun manusia dituntut untuk menjaga keselamatan diri sendiri maupun orang lain dalam, termasuk didalamnya adalah lingkungan hidup tempat dimana manusia tinggal. Keduanya memiliki hubungan erat, dimana jika kerusakan alam terjadi maka makhluk hidup yang tinggal didalam nya pun akan terancam. Oleh karena itu, 
memperhatikan lingkungan hidup dan menjaga kelestariannya juga termasuk pada maslahat yang mesti didapatkan (Dedi, 2016).

Berkaitan dengan hal itu, rumah sakit dituntut untuk memberikan pelayanan yang bermutu sesuai dengan standar yang ditetapkan dan dapat menjangkau seluruh lapisan masyarakat. Pelayanan kesehatan yang bermutu adalah pelayanan kesehatan yang dapat memuaskan setiap pemakai jasa layanan yang sesuai dengan tingkat kepuasan rata-rata penduduk serta penyelenggaraannya sesuai dengan standar dan kode etik profesi yang telah ditetapkan. Menciptakan lingkungan yang sehat seharusnya menjadi salah satu misi organisasi yang bergerak di bidang kesehatan. Sehingga penerapan akuntansi dan manajemen lingkungan menjadi tuntutan penting yang harus dilakukan (Noviani \& Aminah, 2014).

Berkembangnya rumah sakit baik itu milik pemerintah ataupun swasta yang dalam pelaksanaan operasinya menimbulkan kerusakan ekosistem karena adanya limbah medis dan non medis yang tentu memerlukan alokasi biaya penanganan khusus (Noviani \& Aminah, 2014). Dimana saat ini rumah sakit telah menerapkan akuntansi lingkungan, sebagai upaya mengendalian kerusakan lingkungan. Saat ini banyak sekali penelitian terkait penerapan green accounting atau yang lebih kita kenal dengan akuntansi lingkungan di rumah sakit umum, islam maupun syariah (Islamey, 2016) dan juga penerapan akuntansi lingkungan dalam global warming (Martusa, 2009), namun penelitian mengenai penerapan akuntansi lingkungan dan mengenai pandangan maqshid syariah dalam implemetasi belum banyak dilakukan. Sehingga hal inilah yang mendorong penulis untuk memberikan analisis lebih mendalam mengenai peneraan akuntansi lingkungan di rumah sakit umum haji Surabaya dalam pandangan maqashid syariah.

\section{TELAAH TEORITIS}

\subsection{TEORI LEGITIMASI}

Teori legitimasi (Legitimasi Theory) merupakan suatu hal yang penting dalam sebuah perusahaan, terdapat batasan-batasan yang ditekankan oleh norma-norma serta nilai-nilai sosial dan reaksi atas hal itu menjadi penting sebagai pendorong suatu perusahaan untuk melakukan analisis terhadap perilaku organisasi dengan memperhatikan lingkungan. Legitimasi juga dianggap penting karena legitimasi masyarakat kepada sebuah perusahaan menjadi faktor yang strategis bagi perkembangan perusahaan kedepannya (Bangun \& Sunarni, 2014).

Implikasi teori legitimasi terhadap pertanggungjawaban perusahaan terkait permasalahan lingkungan hidup yaitu bahwa pengungkapan tanggung jawab sosial dilakukan perusahaan dalam upayanya untuk mendapatkan legitimasi dari komunitas dimana perusahaan itu berada. Legitimasi ini pada tahapan berikutnya akan mengamankan perusahaan dari hal-hal yang tidak diinginkan. Lebih jauh lagi legitimasi ini akan meningkatkan reputasi 
perusahaan yang pada akhirnya akan berpengaruh pada nilai perusahaan tersebut (Musyarofah, 2013).

\subsection{TEORI STAKEHOLDER}

Teori stakeholder meliputi pengungkapan informasi keuangan, sosial, dan lingkungan merupakan dialog antara perusahaan dengan stakeholdernya dan menyediakan informasi mengenai aktivitas perusahaan yang dapat mengubah persepsi dan ekspektasi (Adam \& McNicholas, 2007).

Stakeholder dan organisasi saling mempengaruhi, hal ini dapat dilihat dari hubungan sosial keduanya yang berbentuk responsibilitas dan akuntabilitas. Kondisi tersebut menciptakan sebuah hubungan timbal balik antara perusahaan dan para stakeholder. Hal ini berarti perusahaan harus melaksankan peranannya secara dua arah yaitu untuk memenuhi kebutuhan perusahaan itu sendiri maupun stakeholders. Karena perusahaan bukanlah entitas yang hanya beroperasi untuk kepentingannya sendiri, namun harus memberikan manfaat stakeholdernya (pemegang saham, kreditor, konsumen, supplier, pemerintah, masyarakat, analisi dan pihak lain). Dengan demikian dapat disimpulkan bahwasan nya teori stakeholders merupakan suatu terori yang mengatakan bahwa keberadaan sebuah perusahaan sangat dipengaruhi oleh dukungan yang diberikan stakeholder kepada perusahaan tersebut, baik dari internal maupun eksternal dengan berbagai latar belakang kepentingan yang berbeda dari setiap stakeholders yang ada (Lindawati \& Puspita, 2015).

\subsection{AKUNTANSI LINGKUNGAN}

Menurut AICPA (American Institute of Certified Public Accounting) dalam buletinnya, Akuntansi didefinisikan sebagai berikut: "Accounting is the art of recording, classifying and summarizing in a significant manner and in the term of money, transaction and event which are and part, at least of financial character and interpreting the result there of (AICPA,1997).

US EPA (United States Environmental Protection Agency) menambahkan bahwa istilah akuntansi lingkungan di bagi menjadi dua. Pertama, akuntansi lingkungan merupakan biaya yang secara langsung berdampak pada perusahaan secara menyeluruh (disebut dengan istilah "biaya pribadi”). Kedua, akuntansi lingkungan juga meliputi biya-biaya individu, masyarakat maupun lingkungan suatu perusahaan yang tidak dapat dipertanggung jawabkan. Akuntansi lingkungan juga didefinisikan sebagai pencegahan, pengurangan, dan atau penghindaran dampak terhadap lingkungan, bergerak dari beberapa kesempatan, dimulai dari perbaikan kembali kejadiankejadian yang menimbulkan bencana atas kegiatan-kegiatan tersebut (Ikhsan, 2008).

Kehadiran akuntansi lingkungan adalah untuk menyempurnakan atau menutupi keterbatasan/kelemahan yang terjadi dalam praktek akuntansi saat ini. Dalam sistem akuntansi lingkungan, manajemen harus mengidentifikasikan, mengklasifikasikan, mengukur dan mengungkapkan biaya-biaya lingkungan, serta mengevaluasi kinerja manajemen/pengolahan 
lingkungan secara berkelanjutan untuk mendukung pengambilan keputusan manajerial (Sambharakreshna, 2009).

\subsection{RUMAH SAKIT UMUM}

Rumah sakit menurut WHO yang dimuat dalam WHO (World Health Organization) Technical Report series No. 122/1957 yang berbunyi : "Rumah Sakit adalah bagian integral dari suatu organisasi sosial dan kesehatan dengan fungsi menyediakan pelayanan kesehatan paripurna, kuratif dan preventif kepada masyarakat, serta pelayanan rawat jalan yang diberikannya guna menjangkau keluarga di rumah" (Bastian, 2008).

Dalam menyelenggarakan pelayanannya, masing-masing rumah sakit baik itu Rumah Sakit Umum ataupun Rumah Sakit Khusus memiliki misi yaitu memberikan pelayanan kesehatan yang bermutu dan terjangkau oleh masyarakat untuk meningkatkan derajat kesehatan masyarakat. Tugas rumah sakit berdasarkan Undang- Undang Nomor 44 tahun 2009 yaitu melakukan upaya pelayanan kesehatan secara berdaya guna dan berhasil guna yang mengutamakan penyembuhan dan pemulihan, yang dilaksanakan secara serasi dan terpadu dengan peningkatan dan pencegahan serta pelaksanaan upaya rujukan, selain itu tugasnya juga memberikan pelayanan kesehatan perorangan secara paripurna (Setya, 2017).

Adapun izin operasional merupakan izin yang diberikan kepada pengelola rumah sakit untuk menyelenggarakan pelayanan kesehatan. Izin operasional pada rumah sakit hanya berlaku untuk jangka waktu 5 tahun dan dapat diperpanjang selama memenuhi persyaratan (Sari, Faridah, \& Setiawan, 2017).

\subsection{RUMAH SAKIT UMUM HAJI SURABAYA}

Menurut pemerintah daerah Jawa Timur rumah sakit umum haji Surabaya adalah rumah sakit milik pemerintah yang didirikan berkenaan peristiwa yang menimpa para jamaah haji Indonesia di terowongan Mina pada tahun 1990 dan meiliki peran meningkatkan pelayanan kesehatan sesuai dengan tugas pokok dan fungsinya (Piranti, 2019).

\subsection{MAQASHID SYARIAH}

Secara bahasa, Maqashid al-syari'ah tersusun dari dua kata, maqashid dan syari'ah. Kata maqashid merupakan bentuk jamak dari kata maqsid yang memiliki arti tuntutan, kesengajaan atau tujuan. Sedang kata syari'ah secara bahasa devinisinya adalah "jalan menuju air". Secara istilah, maqashid alsyari'ah merupakan al-ma'ani allati syuri'at laha al-ahkam (kandungan nilai yang menjadi tujuan pensyariatan hukum). Jadi maqashid al-syari'ah merupakan tujuantujuan yang hendak dicapai dari sebuah penetapan hukum (Cahyani, 2014).

Dapat dipahami secara sederhana bahwa pengertian maqashid syariah adalah tujuan-tujuan, nilai-nilai, ataupun maknamakna yang hendak dicapai dari sebuah penetapan hukum yang dipelihara oleh syara' dalam seluruh hukumnya atau sebagian besar hukumnya, dapat juga dikatakan 
bahwasanya maqashid syariah adalah tujuan akhir dari syari'at dan rahasiarahasia yang diletakkan oleh syara' pada semua hukumnya (Pranata \& Laela, 2020).

Maqashid syariah yang dapat diterapkan dalam pelayanan kesehatan di rumah sakit adalah1;1. Penjagaan agama (hifz ad-diin) terkandung dalam QS. Al Anbiya':107 (yang menjelaskan tentang kerahmatan), QS. Al Maidah: 32 (yang menjelaskan tentang tanggung jawab memelihara kehidupan manusia) dan QS. Ali Imran:110 (yang menjelaskan tentang ummat Isam sebagai ummat terbaik), 2. Penjagaan jiwa (hifz an-nafs) terkandung dalam QS. At Taubah: 108 (yang menjelaskan Integration and Interconnection of Sciences "The Reflection of Islam Kaffah" tentang kecintaan Allah terhadap orang-orang yang menjaga kebersihan). 3. Penjagaan akal (hifz al-'aql) terkandung dalam QS. Al Isra: 36 (yang menjelaskan tentang larangan mengikuti sesuatu apabila tidak memiliki pengetahuan tentang sesuatu). 4. Penjagaan keturunan (hifz an-hasl) terkandung dalam QS. Al Mukminun: 1217 (menerangkan tentang proses terbentuknya manusia), QS. Al Baqoroh: 233 (menerangkan tentang pelaksanaan pemberian ASI dan perencanaan kelahiran), dan 5. Penjagaan harta (hifz al-mal) terkandung dalam HR.Muslim tentang pengelolaan syariah manajemen akuntansi dan keuangan syariah (Sulistiadi \& Rahayu, 2016).

\section{METODE PENELITIAN}

Jenis penelitian yang digunakan adalah penelitian kualitatif deskriptif dengan pendekatan studi literatur. Penelitian ini bertujuan untuk mengetahui penerapan akuntansi lingkungan dalam pandangan maqashid syariah di RSU Haji Surabaya. Sumber data yang digunakan dalam penelitian adalah data sekunder yaitu literature terdahulu dan website resmi rumah sakit.Penelitian menggunakan analisis kualitatif dan studi literature, analisis data dimulai dari proses pengamatan dokumen, yaitu dokumen yang berasal dari penelitian terdahulu dan laporan akuntansi lingkungan di rumah sakit.

Rumah Sakit Umum (RSU) Haji Surabaya adalah rumah sakit milik Pemerintah propinsi Jawa Timur yang didirikan berkenaan peristiwa yang menimpa para Jamaah Haji Indonesia di terowongan Mina pada tahun 1990. Dengan adanya bantuan dana dari Pemerintah Arab Saudi dan dilanjutkan dengan biaya dari Pemerintah propinsi Jawa Timur, berhasil dibangun gedung beserta fasilitasnya yang resmi dibuka pada tanggal 17 April 1993, sebagai RSU tipe C. Pada tahun 1998 berkembang menjadi RSU tipe B Non Pendidikan dan pada tanggal 30 Oktober 2008 sesuai SK, RSU Haji Surabaya berubah status menjadi RSU tipe B Pendidikan. 


\section{HASIL DAN DISKUSI}

\subsection{LIMBAH HASIL KEGIATAN OPERASIONAL RUMAH SAKIT UMUM HAJI SURABAYA}

Limbah yang dihasilkan dari kegiatan operational di Rumah Sakit umum haji Surabaya terbagi dalam dua bentuk yaitu limbah cair dan limbah padat. Limbah cair di rumah sakit ini berasal dari semua air buangan termasuk tinja, limbah cair domestik berupa buangan kamar dari rumah sakit yang mungkin mengandung mikroorganisme, bahan kimia beracun, dan radioaktif serta darah yang berbahaya bagi kesehatan. Jenis limbah cair rumah sakit terdiri dari berbagai macam aktivitas yaitu pelayanan mandi, cuci, kakus pasien yang berupa limbah cair dalam kamar mandi dan pencucian peralatan yang digunakan, limbah pengobatan/perawatan klinis terutama berasal dari kegiatan pencucian ginjal dan pencucian peralatan dan limbah dari ruangan operasi (Fitri, 2014).

Sementara untuk limbah padat berasal dari limbah medis dan non medis. Limbah medis padat terdiri dari limbah infeksius, limbah patologi, limbah benda tajam, limbah farmasi, limbah sitotoksis, limbah kimiawi, limbah radioaktif, limbah kontainer bertekanan dan limbah dengan kandungan logam berat yang tinggi. Prosedurnya yaitu mengumpulkan sampah dari kamar-kamar pasien, Koridor dan Nurse Station menggunakan troli khusus yang tertutup (Pujiati, 2004).

\subsection{PENGELOLAAN LIMBAH RUMAH SAKIT}

\section{Limbah Cair}

Rumah Sakit Umum (RSU) Haji Surabaya mengolah limbah cair yang dihasilkan dengan IPAL lumpur aktif. Kapasitas pengolahan maksimal yang di desain sebesar $200 \mathrm{~m} 3 /$ hari dengan beban BOD maksimal 0,96 kg BOD5/ m3.hari (Manual Operation Sewage Water Treatmet Plan, 1995). Data hasil analisa limbah pada tahun 2011 sampai 2013 didapatkan $80 \%$ efluen air limbah tidak memenuhi baku mutu. Konsentrasi COD mencapai 108,9 mg/l, BOD 36,5 mg/l, TSS $31 \mathrm{mg} / \mathrm{l}$, NH3 Bebas 0,54 mg/l, Phosphat 35,8 mg/l. Sedangkan baku mutu limbah cair bagi kegiatan rumah sakit yaitu konsentrasi COD maksimal 80 mg/l, BOD 30 mg/l, TSS 50 mg/l, NH3 Bebas $0,1 \mathrm{mg} / \mathrm{l}$, dan Phosphat $2 \mathrm{mg} / \mathrm{l}$.

Sistem IPAL RSU Haji Surabaya terdiri dari bak equalisasi, bak lumpur aktif, sedimentasi, klorinasi, dan kolam kontrol. Hingga saat ini belum diketahui secara pasti penyebab menurunnya kualitas efluen air limbah sehingga belum dapat dilakukan tindakan yang tepat untuk mengoptimalkan kualitas efluen air limbah agar memenuhi baku mutu yang ditetapkan (Suparmadja, 2015).

Dalam upaya pemantauan kualitas efluen limbah cair, RSU Haji Surabaya melakukan analisa rutin setiap triwulan yang dilakukan oleh laboratorium bersertifikat KAN dan diketahui bahwasannya kualitas efluen yang melebihi baku mutu. Hal ini menunjukkan bahwa terjadi penurunan kinerja IPAL Lumpur Aktif RSU Haji Surabaya yang ditandai dengan 
penurunan kualitas efluen limbah cair yang melebihi baku mutu pada setiap periode pemeriksaan (Said, 2008).

Pada tahap awal, limbah cair RSU Haji Surabaya dialirkan menuju bak equalisasi, bak ini berfungsi untuk mengatur debit air limbah agar konstan. Limbah dari bak equalisasi air limbah dipompa ke bak lumpur aktif, di dalam bak ini air limbah dihembus dengan udara dari blower. Hal ini bertujuan agar bakteri dalam air limbah dapat melakukan metabolisme untuk mengurai bahan organik. Energi hasil penguraian bahan organik digunakan bakteri untuk proses pertumbuhan dan pembentukan sel baru. Dengan demikian di dalam bak aerasi akan tumbuh biomassa dengan jumlah yang besar, dan biomassa inilah yang akan mengurai bahan organik di dalam air limbah. Dari bak lumpur aktif ini air limbah yang bercampur dengan biomassa dialirkan ke bak pengendap akhir untuk dipisahkan (Suparmadja, 2015).

2. Limbah Padat

Rumah sakit umum Haji Surabaya mengahasilkan dua jenis limbah padat yaitu limbah padat medis dan limbah padat non-medis. Adapun ruangan yang menghasilkan sampah padat medis dan non - medis sekaligus adalah ruang Bedah Sentral, Rontgent, Rehabilitasi Medik, Unit Gawat Darurat (UGD), Unit Perawatan Intensif atau Intensive Care Unit (ICU), Patologi, Ruang Jenazah, Laboratorium, Rawat Inap, Pavilyun, Poliklinik, dan Instalasi Farmasi. Sedangkan sumber sampah non-medis saja adalah Ruang Tunggu, Instalasi Dapur/Gizi, Kantin, Kantor Administrasi, dan halaman Rumah Sakit (Pujiati, 2004).

Secara umum, jenis sampah medis yang paling banyak ditemukan adalah jarum suntik, kateter, kapas, dan selang infus. Sedangkan sampah nonmedis yang paling banyak ditemukan adalah makanan sisa (nasi), potongan sayur, dan plastik pembungkus. Produksi sampah padat dari Rumah Sakit Umum Haji Surabaya rata-rata per hari mencapai 51,06 kg (0,34 M 3 ) untuk sampah padat medis dan 192,07 kg (1,01 M 3 ) untuk sampah padat nonmedis. Sumber penghasil sampah medis terbanyak adalah Unit Gawat Darurat (UGD) yaitu sebesar $12,76 \mathrm{~kg}$ (0,05 M3 ). Sedangkan penghasil sampah non-medis terbesar adalah Pavilyun yaitu sebesar 31,99 kg (0,09 M 3 ) (Triana \& Keman, 2006).

Pengelolaan sampah padat medis dan non -medis dikelola oleh karyawan Rumah Sakit Umum Haji Surabaya yang bertanggungjawab atas kebersihan ruang kantor, UGD, ICU, Rehabilitasi Medik, Farmasi, Laboratorium, Ruang Rontgent, Laundry dan Kamar Jenazah. Pengelolaan sampah dibantu oleh karyawan dari rekanan cleaning service dan karyawan dari CV. Guna Adi Graha yang bertanggung jawab kebersihan unit perawatan dan sekitarnya, karyawan dari Bali Dunia yang bertanggung- jawab kebersihan unit rawat jalan (poliklinik) dan sekitarnya, karyawan lain dari Integrated Service Solution (ISS) yang bertanggung jawab kebersihan unit pavilyun. Karyawan dari berbagai instalasi dan CV sudah mencukupi untuk pengelolaan sampah di rumah sakit ini (RSU Haji Surabaya, 2003). 
Tahapan pengelolaan sampah padat medis dan non-medis di Rumah Sakit Umum Haji Surabaya adalah (1) penimbunan, meliputi aktivitas penampungan sampah padat di bak sampah; (2) penyimpanan sementara, untuk sampah padat medis dan non-medis harus terpisah; (3) pengumpulan, sebaiknya tidak dilakukan dalam waktu yang terlalu lama dan dilakukan setelah 2/3 bak sampak terisi penuh; (4) pengangkutan, sebaiknya dilakukan sebelum aktivitas rumah sakit dimulai pada pagi hari, sehingga tidak mengganggu aktivitas utama rumah sakit; (5)pengolahan dan pemanfaatan kembali, dilakukan hanya pada sampah yang dapat dimanfaat kan dan diolah kembali; dan (6) pemusnahan akhir, untuk sampah padat medis dibakar di insinerator oleh petugas pengelola sampah rumah sakit dalam waktu yang tidak terlalu lama, dan untuk sampah padat non medis dilakukan oleh petugas dari Dinas Kebersihan Kota Surabaya (Ditjen PPM dan PLP, 2002).

Pemusnahan akhir sampah padat medis dan non -medis dilakukan secara terpisah. Sampah padat medis dimusn ahkan dalam insinerator, dilakukan 2-3 hari sekali tergantung jumlah sampah padat medis yang dihasilkan. Pembakaran dilakukan pada jam 16.00 untuk menghindari gangguan pada aktivitas rumah sakit pada pagi harinya. Tinggi cerobong insinerator masih lebih rendah dari gedung bertingkat yang ada di sekitarnya. Sayangnya suhu pembakaran insinerator hanya mencapai 800o C, sehingga residu pembakaran ada yang masih dalam bentuk utuh seperti botol, kaca dan jarum suntik. Residu pembakaran ditanam dalam lubang pembuangan ukuran 2,5 x 1,5 x 2,5 M 3 (Sulistyorini, 2005).

Pengolahan limbah medis maupun non medis dalam rumah sakit yang baik bertujuan untuk menciptakan lingkungan rumah sakit bersih, nyaman dan terbebas dari pencemaran karena penumpukan sampah. Kenyamanan bagi pasien dan masyarakat merupakan prioritas bagi rumah sakit, sehingga sustainibilitiy sebuah institusi tidak terancam, hal ini membuktikan nilai soial perusahaan dan nilai social masyarakat berjalan selaras. pengelolaan limbah adalah bukti bagi rumah sakit umum Haji Surabaya sebagai salah satu rumah sakit yang memperhatikan tujuan dalam maqashid syariah yaitu hifdzul bi'ah atau menjaga lingkungan (Busriyanti, 2016).

\subsection{AKUNTANSI LINGKUNGAN DI RUMAH SAKIT HAJI SURABAYA}

Pentingnya akuntansi lingkungan pada dasarnya menuntut kesadaran penuh perusahaan-perusahaan maupun organisasi lainnya yang telah mengambil manfaat dari lingkungan (Burhany, 2014).

Implementasi akuntansi lingkungan ditujukan untuk menghasilkan informasi yang berkaitan dengan lingkungan. Dengan demikian maka bagi perusahaan yang menerapkan akuntansi lingkungan akan ada tambahan biaya untuk menghasilkan informasi itu. Penting bagi perusahaan-perusahaan atau organisasi lainnya agar dapat meningkatkan usaha dalam mempertimbangkan konservasi lingkungan secara berkelanjutan (Suaryana, 2011).

Akuntansi lingkungan menurut pihak rumah sakit adalah biaya yang timbul dari kegiatan operasional rumah sakit yang bertujuan untuk untuk mengelola dan mencegah terjadinya kerusakan, di lingkungan rumah sakit, baik itu limbah maupun taman. Biaya ini keluarkan jika terjadi kerusakan 
ataupun untuk mencegah terjadinya limbah yang dihasilkan dari aktifitas rumah sakit. Seperti biaya cleaning service yang setiap saat membersihkan area rumah sakit untuk menjaga kenyamanan pengunjung maupun pasien. Biaya yang dikeluarkan pihak Rumah sakit dikelompokkan kedalam laporan keuangan rumah sakit, yang meliputi biaya- biaya pengolahan limbah dan pengelolaan lingkungan rumah sakit (Bangun \& Sunarni, 2014).

Penerapan akuntansi lingkungan pada RSU Haji Surabaya ditunjukan pada tabel Tabel 1.

Tabel 1. Pemerintah Provinsi Jawa Timur Laporan Realisasi Anggaran Tahun Anggaran 2019

Urusan Pemerintahan : ( 102 ) Kesehatan

Organisasi : ( 0500 ) Rumah Sakit Haji Surabaya

\begin{tabular}{|c|c|c|c|c|c|}
\hline & & Jumlah & (Jutaan Rp) & $\begin{array}{l}\text { Bertambah } \\
\text { (Berkurang) }\end{array}$ & \\
\hline No & Uraian & $\begin{array}{l}\text { Anggaran } \\
\text { Setelah } \\
\text { Perubahan }\end{array}$ & Realisasi & (Jutaan Rp) & $\%$ \\
\hline 1 & 2 & 3 & 4 & $5(=4-3)$ & 6 \\
\hline 2.1 & Belanja & 343.149 & 299.506 & -43.643 & 12,72 \\
\hline 2.1 .1 & Belanja pegawai & 107.516 & 101.479 & -6.036 & $-5,61$ \\
\hline 2.1 .2 & Belanja barang \& jasa & 180.237 & 155.210 & -25.027 & $\begin{array}{c}- \\
13,89 \\
\end{array}$ \\
\hline 2.2 & Belanja modal & 55.397 & 42.816 & -12.580 & 22,71 \\
\hline 2.2 .2 & $\begin{array}{l}\text { Belanja modal peralatan \& } \\
\text { mesin }\end{array}$ & 54.897 & 42.349 & -12.547 & $\begin{array}{c}- \\
22,85 \\
\end{array}$ \\
\hline 2.2 .4 & $\begin{array}{l}\text { Belanja modal jalan, irirgasi \& } \\
\text { jaringan }\end{array}$ & 500 & 467 & -33 & $-6,60$ \\
\hline
\end{tabular}

Sumber: https://rsuhaji.jatimprov.go.id

Berdasarkan laporan keuangan rumah sakit haji tahun 2019 disebutkan bahwasan nya anggaran untuk biaya lingkungan ditunjuk dengan dikelurkan nya biaya jalan, irigasi dan jaringan. Rincian mengenai biaya pengolahan sampah, cleaning service, pemeliharaan geduang dan bangunan, serta pemeliharaan jalan, irigasi, instalasi dan jaringan dijelaskan dalam catatan atas laporan keuangan (CALK).

Tabel 2. Pemeliharaan Peralatan dan Kelengkapan Sarana dan Prasarana

\begin{tabular}{clcccc}
\hline \multirow{2}{*}{ Kode Rek } & \multicolumn{1}{c}{ Uraian } & Jumlah & $\begin{array}{c}\text { (Jutaan } \\
\text { Rp) }\end{array}$ & $\begin{array}{c}\text { Bertambah } \\
\text { (berkurang) }\end{array}$ & \\
\cline { 3 - 6 } & \multicolumn{1}{c}{2} & $\begin{array}{c}\text { Anggaran } \\
\text { Setelah } \\
\text { perubahan }\end{array}$ & Realisasi & (Jutaan Rp) & $\%$ \\
\hline 1 & 3 & 4 & 5 & 6 \\
\hline 5.2 .2 .03 .05 & $\begin{array}{l}\text { Belanja Langganan } \\
\text { Multimedia }\end{array}$ & 396 & 374 & $(22)$ & 94,38 \\
\hline \multirow{2}{*}{2.031} & $\begin{array}{l}\text { Pemeliharaan Peralatan } \\
\text { dan Kelengkapan Sarana } \\
\text { dan Prasarana }\end{array}$ & 4.500 & 4.272 & (228) & 94,93 \\
\hline 5.2 .2 & BELANJA BARANG & 4.500 & 4.272 & $(228.295 .81$ & 94,93 \\
\hline
\end{tabular}




\begin{tabular}{|c|c|c|c|c|c|}
\hline \multirow[b]{2}{*}{ Kode Rek } & \multirow[b]{2}{*}{ Uraian } & Jumlah & $\begin{array}{l}\text { (Jutaan } \\
\text { Rp) }\end{array}$ & $\begin{array}{l}\text { Bertambah } \\
\text { (berkurang) }\end{array}$ & \\
\hline & & $\begin{array}{l}\text { Anggaran } \\
\text { Setelah } \\
\text { perubahan }\end{array}$ & Realisasi & (Jutaan Rp) & $\%$ \\
\hline 1 & 2 & 3 & 4 & 5 & 6 \\
\hline & DAN JASA & & & $8,00)$ & \\
\hline 5.2.2.03.18 & Belanja Jasa Dekorasi & 75 & 75 & $(0)$ & 99,60 \\
\hline 5.2 .2 .03 .20 & $\begin{array}{l}\text { Belanja Jasa Cleaning } \\
\text { Service }\end{array}$ & 4.092 & 3.880 & $(212)$ & 94,82 \\
\hline 5.2 .2 .03 .26 & $\begin{array}{l}\text { Biaya Pengelolaan } \\
\text { Sampah }\end{array}$ & 167 & 164 & (3) & 98,20 \\
\hline 5.2 .2 .03 .03 & $\begin{array}{l}\text { Belanja Pemeliharaan } \\
\text { Gedung dan Bangunan }\end{array}$ & 10 & 8 & (2) & 83,27 \\
\hline 5.2 .2 .20 .04 & $\begin{array}{l}\text { Belanja Pemeliharaan } \\
\text { Jalan, Irigasi, Instalasi } \\
\text { dan Jaringan }\end{array}$ & 156 & 144 & (12) & 92,62 \\
\hline $\begin{array}{l}5.2 .2 .2 .03 .0 \\
2\end{array}$ & Belanja Air & 653 & 615 & (37) & 94,35 \\
\hline 5.2.2.03.03 & Belanja Listrik & 2.981 & 2.876 & $(105)$ & 96.48 \\
\hline
\end{tabular}

Realisasi untuk kegiatan penyediaan peralatan dan kelengakapan sarana dan prasarana sudah mencapai $95,44 \%$ jika dibandingakan dengan anggaran belanja rumah sakit untuk penyediaan/peningkatan/pe meliharaan sarana/ prasarana fasilitas kesehatan yang bekerjasama dengan Badan Penyelenggara Jaminan Sosial Kesehatan yaitu sebesar 5.000.000.000,00, hal ini menunjukan bahwa lebih dari $90 \%$ anggaran belanja rumah sakit digunakan untuk belanja barang dan jasa kepentingan lingkungan. Berdasarkan laporan dalam CALK rumah sakit umum Haji Surabaya sangat mengutamakan kebersihan lingkungan dan impelementasi nilai sosial rumah rumah sakit kepada para pasien. Hal ini merupakan salah bentuk penerpan nilai yang ada dalam maqashid syariah yaitu hifdzul nafs atau menjaga jiwa (Sulistiadi \& Rahayu, 2016). Sesuai dengan perlakuan dalam akuntansi, RSU Haji Surabaya melakukan proses pencatatan yaitu meliputi: Identifikasi, Pengakuan, Pencatatan, Penyajian dan Pengungkapan (Ahmad, 2012).

1. Pengidentifikasian

Pengidentifikasian merupakan tahap awal dari tahapan siklus akuntansi, dengan melakukan identifikasi terhadap transaksi-transaksi bisnis yang dilakukan oleh suatu perusahaan dalam periode tertentu. Pertama kali rumah sakit menetukan biaya lingkungan untuk pengelolaan biaya penanggulangan yang terjadi dalam kegiatan operasional yaitu mengidentifikasi dampak negatifnya (Agustia, 2010). Rumah sakit umum Haji Surabaya mengidentifikasikan semua kegiatan medis dan non medis yang memiliki potensi menimbulkan pengaruh lingkungan dan mengalokasikan biaya untuk pengelolaan lingkungannya.

Adapun biaya- biaya yang dikeluarkan oleh pihak rumah sakit terdiri dari biaya air, biaya IPAL, biaya jasa dekorasi, biaya cleaning service, biaya pengelolaan sampah, biaya pemeliharaan gedung dan bangunan dan biaya pemeliharaan jalan, irigasi, instalasi dan jaringan. Adapula biaya listrik, 
tetapi biaya listrik diakumulasikan ke dalam biaya listrik secara keseluruhan dengan biaya listrik rumah sakit secara umum, karena tidak dimungkinkan untuk menghitung biaya listrik secara tersendiri.

Rumah Sakit mengidentifikasi biaya yang timbul selama pengelolaan limbah. Proses pengidentifikasian disesuaikan dengan kebijakan rumah sakit. Tidak adanya standar yang mengatur secara khusus mengenai perlakuan biaya yang telah dikeluarkan untuk pengelolaan efek negatif dari sisa hasil operasional perusahaan, maka sudah tepat jika rumah sakit dalam mengidentifikasi transaksi terkait pengelolaan limbah dan melaporkan biayabiaya atas pengelolaan limbah ke dalam laporan operasional rumah sakit (Bangun \& Sunarni, 2014).

2. Pengakuan

Pengakuan biaya dalam rekening dilakukan pada saat menerima manfaat dari sejumlah nilai yang telah dikeluarkan. Rumah sakit Umum Surabaya menggunakan metode akrual basis yaitu mengakui sebagai biaya apabila sudah memberikan manfaat bagi Rumah Sakit. Pengakuan biaya dari kegiatan pengelolaan limbah dinyatakan dalam satuan rupiah dan dicantumkan dalam laporan operasional rumah sakit, sehingga diharapkan dapat memberikan informasi yang relevan, andal, dapat dibandingkan, dan dapat dipahami para pengguna laporan keuangan (Sari, 2017).

Rumah sakit umum haji Surabaya sudah melakukan proses akuntansi sesuai dengan tahapan yang ada. Mengenai pengakuan biaya pengolahan limbah, pihak rumah sakit memasukannya ke dalam biaya operasional. Pencatatan dilakukan oleh operator SIMBADA serta fungsi akuntansi yang selanjutnya dilakukan rekonsiliasi setiap triwulan.

\section{Pengukuran}

Pihak Rumah sakit umum Haji Surabaya dalam mengukur biaya pengelolaan limbah adalah menggunakan satuan moneter. Kusumawati \& Sudarsono (2015) mengungkapkan bahwasannya pengukuran (measurement) adalah penentuan jumlah rupiah yang harus diletakkan pada suatu objek yang terlibat dalam suatu transaksi keuangan, dan dijadikan data dasar dalam penyusunan statemen keuangan. Sampai saat ini pengukuran terkait dengan biaya lingkungan belum ditetapkan standar pengukurannya. Sehingga pengukuran biaya lingkungan lebih berdasarkan pada kebijakan yang ada disuatu perusahaan.

\section{Penyajian}

Rumah umum Haji Surabaya menyajikan biaya lingkungan bersamaan dengan biaya yang berhubungan dengan pengelolaan limbah. Penyajian tersebut dilakukan bersama sebagai sub-sub biaya operasional. Sehingga penyajian terkait kegiatan pengelolaan limbah tersebut akan memudahkan para pembaca laporan keuangan untuk memahami dan membandingkan kinerja yang dicapai.

Oleh karena itu, rumah sakit juga perlu untuk membuat akun khusus untuk biaya pengelolaan limbah dalam laporan keuangannya, sehingga akan memudahkan dalam menelusuri setiap biaya yang dikeluarkan dan nantinya 
diharapkan pihak pengguna/pembaca laporan keuangan, baik internal maupun eksternal memiliki kepercayaan bahwa rumah sakit telah mengelola limbahnya dengan baik, hal tersebut ditunjukkan dengan adanya biaya khusus terkait pengelolaan limbah, sehingga akan memudahkan mengetahui kinerja rumah sakit. Hal ini juga menjadi suatu kelebihan bagi sebuah rumah sakit, karena tidak semua rumah mencatatnya dalam akun khusus.

\section{Pengungkapan}

Pengungkapan merupakan tahap terakhir dari proses perlakuan akuntansi. Pengungkapan dalam akuntansi lingkungan merupakan jenis pengungkapan suka rela, berkaitan dengan masalah bahwa suatu informasi keuangan sebuah instansi seperti di rumah sakit diungkapkan atau tidak. Namun kegiatan pengelolaan limbah rumah sakit perlu untuk diungkapkan terutama terkait transaksi yang dilakukan, sehingga nantinya akan memberikan informasi yang berguna bagi para stakeholders, terlebih dalam laporan keuangan yang disajikan (Widialoka, 2017).

Pengungkapan sama halnya seperti penyempurnaan dalam proses akuntansi biaya lingkungan. Biaya yang timbul dari kegiatan pengelolaan limbah oleh rumah sakit, diungkapkan ke laporan operasional. Pengungkapan tersebut bermanfaat untuk mengetahui setiap transaksi yang terjadi selama kegiatan pengelolaan limbah rumah sakit.

Dapat diketahui pada dasarnya Rumah umum Haji Surabaya sudah melakukan proses penerapan akuntansi lingkugan dengan baik, hal itu dapat terlihat dari banyaknya anggaran belanja rumah sakit yang diperuntukan untuk proses perbaikan lingkungan rumah sakit. Hal ini juga diungkapkan dalam laporan keuangan rumah sakit.

\subsection{TANGGUNG JAWAB SOSIAL RUMAH SAKIT}

Tanggung jawab sosial merupakan suatu manifestasi kepedulian lingkungan terhadap tanggung jawab sosial dari perusahaan. Pertanggung jawaban sosial timbul jika organisasi mempunyai tanggung jawab terhadap masalah sosial dan lingkungan disekitamya. Kemajuan teknologi mendorong adanya kerjasama antara pemerintah dan perusahaan untuk terus menjaga kelestarian lingkungan dan sekitarnya agar keberadaan faktor- faktor sumber daya ekonomis dapat terus dijaga kelestariannya (Trisnawati, 2014).

Setiap organisasi atau perusahaan yang menghasilkan produk atau jasa sebagai output atas kegiatan operasionalnya otomatis memiliki tanggung jawab terhadap lingkungan di sekitar perusahaan (Lindawati \& Puspita, 2015).

Masyarakat adalah salah satu unsur yang sangat penting dalam menjamin keberlangsungan kegiatan operasional rumah sakit. Pelayanan kesehatan rumah sakit semata-mata dilakukan untuk memenuhi kebutuhan masyarakat terkait kesehatan. Oleh karena itu rumah sakit secara tidak langsung memiliki tanggung jawab tersendiri bagi masyarakat. Tanggung jawab yang dimaksud adalah bagaimana organisasi tersebut mengintegrasikan perhatian terhadap lingkungan sekitar perusahaan (Adni, Susilo, \& Prasetya, 2014). 
Dalam menunaikan tanggung jawab tersebut rumah sakit umum haji Surabaya melakukan segala upaya yang terbaik untuk menciptakan kenyamanan bagi pasien dan staf rumah sakit. Salah satu upaya tersebut adalah menjaga lingkungan rumah sakit agar tetap bersih dan terjaga. Selain merupakan kewajiban yang harus ditunaikan, hal ini juga sebagai bentuk tanggung jawab rumah sakit terhadap masyarakat sekitar (Kusuma, Asmeri, \& Begawati, 2010).

Tanggung jawab sosial juga menjadi salah bentuk kepedulian rumah sakit. Kepedulian tersebut dapat ditunjukan dalam beberapa hal seperti menjaga lingkungan, jaminan kerja, hak asasi manusia, interaksi dan keterlibatan perusahaan dengan masyarakat. Termasuk didalamnya menyediakan sarana dan prasarana yang menunjang kemudahan bagi pasien dan pekerja rumah sakit. Sebagai rumah sakit Islam tentu saja fasilitas berupa tempat beribadah, tempat beristirahat, kamar mandi yang terpisah antara wanita dan pria dan perlengkapan penunjang lainnya disediakan oleh pihak rumah sakit. Hal ini menunjukan bahwa rumah sakit umum haji Surabaya mengutamakan nilai- nilai dalam Maqashid Syariah yaitu hifdzul diin atau menjaga agama (Busriyanti, 2016).

Tangguang jawab sosial didalam rumah sakit umum haji Surabaya juga ditunjukan dengan adanya pengeluaran biaya untuk program pembinaan lingkungan sosial. Rincian mengenai biaya dapat dilihat pada Tabel 3.

Tabel 3. Rincian Program Pembinaan Lingkungan Sosial

\begin{tabular}{|c|c|c|c|c|c|}
\hline \multirow[b]{2}{*}{ Kode Rek } & \multirow[b]{2}{*}{ Uraian } & Jumlah & $\begin{array}{l}\text { (Jutaan } \\
\text { Rp) }\end{array}$ & $\begin{array}{l}\text { Bertambah } \\
\text { (Berkurang) }\end{array}$ & \\
\hline & & $\begin{array}{c}\text { Anggaran } \\
\text { Setelah } \\
\text { perubahan }\end{array}$ & Realisasi & (Jutaan Rp) & $\%$ \\
\hline 1 & 2 & 3 & 4 & 5 & 6 \\
\hline 4.3 & $\begin{array}{l}\text { Program pembinaaaan } \\
\text { lingkungan sosial }\end{array}$ & 5.000 & 4.912 & -88 & 98,25 \\
\hline 43.006 & $\begin{array}{l}\text { Penyediaan/peningkatan } \\
\text { /pemel iharaan sarana/ } \\
\text { prasarana fasilitas } \\
\text { kesehatan yang } \\
\text { bekerjasama dengan } \\
\text { Badan Penyelenggara } \\
\text { Jaminan Sosial } \\
\text { Kesehatan }\end{array}$ & 5.000 & 4.912 & -88 & 98,25 \\
\hline $\begin{array}{l}5.2 .2 .20 .0 \\
2\end{array}$ & $\begin{array}{l}\text { Belanja Pemeliharaan } \\
\text { Peralatan dan Mesin }\end{array}$ & 5.000 & 4.912 & -88 & 98,25 \\
\hline
\end{tabular}

Sumber: htpps://rsuhaji.jatimprov.go.id

\subsection{PENERAPAN AKUNTANSI LINGKUNGAN DI RSU HAJI SURABAYA}

Untuk pengolahan limbah dari kegiatan operasional, rumah sakit perlu mengalokasikan biaya didalamnya. Perhitungan biaya dalam penanganan limbah tersebut diperlukan adanya perlakuan akuntansi yangtersistematis secara benar. Perlakuan terhadap masalah penanganan limbah hasil operasional perusahaan ini menjadi sangat penting dalam kaitannya sebagai 
sebuah kontrol dan tanggung jawab perusahaan terhadap lingkungannya. Akuntansi lingkungan merupakan bidang ilmu akuntansi yang berfungsi untuk mengidentifikasikan, mengakui, mengukur, menilai, menyajikan dan mengungkapkan akuntansi lingkungan. Dalam hal ini pencemaran dan limbah produksi yang merupakan salah satu contoh dampak negatif dari operasional rumah sakit yang membutuhkan sistem akuntansi lingkungan sebagai pengendali terhadap pertanggung jawaban rumah sakit (Sari, 2017).

Penerapan akuntansi lingkungan di rumah sakit umum haji Surabaya dibuktikan dengan adanya pos- pos biaya yang dikeluarkan oleh rumah sakit untuk pengelolaan lingkungan, gedung dan bangunan serta pengelolaan limbah rumah sakit. Prosedur tetap (protap) yangberhubungan dengan penge-lolaan sampah padat medis dan non-medis yang dimiliki oleh RumahSakit Umum Haji Surabaya adalah Protap Penanganan LimbahMedis, Protap Pembuangan Limbah Medis Benda Tajam, Protap Pembuangan Limbah Non-medis dan Protap Pengoperasian Insinerator (Triana dan Keman, 2006).

Anggaran belanja rumah sakit untuk program peningkatan sarana dan prasarana aparatur Rp. 8.707.050.900,00, yang terbgai dalam beberapa pos belanja yaitu belanja barang dan jasa sebesar Rp. 4.207.050.900,00, termasuk didalamnya belanja air, listrik, jasa cleaning service, pengelolaan sampah, pemeliharaan Gedung dan bangunan, jasa dekorasi, dan belanja pemeliharaan jalan, irigasi, instalasi dan jaringan, serta biaya program pembinaan sosial sebsar Rp. 4.912.435.062,00. Akuntansi lingkungan menjadi sangat penting bagi bagi setiap perusahaan atau instansi, karena hal ini akan berdampak pada kecendrengunan keberpihakan masyarakat sehingga akan berpengaruh terhadap citra sebuah perusahaan (Debora \& Ismail, 2013).

\subsection{IMPLEMENTASI MAQASHID SYARIAH DI RSU HAJI SURABAYA}

Pengelolaan limbah di rumah sakit umum Haji Surabaya adalah salah satu upaya untuk penyelarasan nilai sosial sebuah institusi dengan nilai sosial masyarakat dengan upaya mengurangi volume atau bahaya limbah melalui proses fisika atau kimia. Dalam upaya pengelolaan limbah upaya pertama yang dilakukan adalah mengurangi volume bahaya limbah yang dikeluarkan ke lingkungan yang meliputi upaya mengurangi limbah pada sumbernya (Bapedal, 2004). Perwujudan pengolahan limbah rumah sakit sudah dijalankan dengan baik dan sesuai dengan ketentuan, hal ini dibuktikan dengan adanya kerjasama pemerintah setempat, perusahaan incinerator yang telah memiliki izin operasi dan pengelolaan lingkungan rumah sakit yang bersih dan nyaman. Hal ini merupakan implementasi dari tujuan maqashid yaitu hifdzul bi'ah atau menjaga lingkungan (Busriyanti, 2016).

Sebagai salah satu rumah sakit haji, RSU Haji Surabaya memenuhi hak para pasien yang merupakan bentuk pelayanan rumah sakit yaitu memberikan pelayanan kebersihan secara personal maupun lingkungan, adanya pembersihan lingkungan akan taman, ruanganruangan pada rumah sakit dan tentu saja pada ruangan pasien agar kebersihan lingkungan terjaga dan memberikan dampak positif kepada pasien baik yang dalam keadaan rawat inap ataupun rawat jalan yang sedang berobat di rumah sakit. 
Kebersihan akan kamar kecil (WC) merupakan hal yang paling isu pada setiap tempat yang dikunjungi, karena merupakan sebuah tempat yang sangat kursial untuk ditentukan bagaimana keadaan pelayanan dengan hanya melihat kebersihan kamar kecil pada tempat tersebut (Sunawi, 2012).

Selain hal tersebut sebagai salah satu rumah sakit islam, tentu penyediaan fasilitas dan sarana ibadah menjadi hal yang harus diberikan. Fasilitas-fasilitas inilah memudahkan untuk umat muslim yang sedang berada di rumah sakit khususnya yang berpredikat Islami, pelayanan akan orang yang berkunjung dan keluarganya memberikan amenity atau rasa nyaman dan aman. Bukan hanya masjid, pelayanan parkir yang dapat dipercaya dan memberikan rasa aman pun meningkatkan kepuasan pasien dan keluarganya, dan serta adanya akses yang mudah untuk berbelanja seperti halnya supermarket ataupun wartel. Rumah sakit umum haji Surabaya menyedikan fasilitas penunjang pasien seperti sarana ibadah, kamar mandi yang terpisah antara wanita dan laki-laki, adanya ruang tertutup untuk ibu menyusui serta ruang istirahat adalah bentuk tanggung jawab sosial rumah sakit yang harus dilaksanakan dan merupakan perwujudan dari maqashid syariah yaitu hifdul diin atau menjaga agama (Dedi, 2016).

\section{SIMPULAN}

Penelitian ini memiliki tujuan untuk mengetahui penerapan akuntansi lingkungan di RSU Haji Surabaya dalam pandangan maqashid syariah. Berdasarkan hasil penelitian diketahui bahwasannya rumah sakit umum Haji Surabaya sudah menerapkan akuntansi lingkungan dan sudah melakukan tahapan perlakuan akuntansi untuk biaya pengelolaan limbah. Biaya yang timbul terkait pengelolaan limbah di RSU Haji Surabaya terdiri dari biaya air, biaya jasa dekorasi, biaya cleaning service, biaya pengelolaan sampah, biaya pemeliharaan gedung dan bangunan dan biaya pemeliharaan jalan, irigasi, instalansi dan jaringan.

Penerapan akuntansi lingkungan di RSU Haji Surabaya merupakan implementasi tujuan dalam maqashid syariah. Pengeluaran biaya pemeliharaan lingkungan dan bangunan serta biaya pengolahan limbah rumah sakit sebagai wujud penerapan atas tujuan hifzdul nafs atau menjaga jiwa dan hifdzul bi'ah atau menjaga lingkungan, dimana rumah sakit sangat memprioritaskan kenyamanan pasien dan juga masyarakat sekitar rumah sakit. Selain itu biaya untuk penyediaan fasilitas dan sarana prasana terkait penyediaan ruang ibadah, tempat wudlu dan kamar mandi terpisah adalah implementasi dari hifdzul diin atau menjaga agama.

Adapun keterbatasan dalam penelitian ini antara lain: (1) Sumber data yang digunakan dalam penelitian ini adalah data sekunder, yang diperoleh dari jurnal penelitian terdahulu dan website resmi rumah sakit dan tanpa adanya proses wawancara atau observasi langsung. (2) Pada penelitian ini, penulis hanya menggunakan data laporan keuangan satu rumah sakit saja, sehingga belum menggambarkan bagaimana penerapan akuntansi lingkungan pada rumah sakir di Indonesia secara keseluruhan. 


\section{DAFTAR PUSTAKA}

Adams, C. A., \& McNicholas, P. (2007). Making a Difference : Sustainability Reporting Accountability and Organizational Changed. Accounting and Auditing Journal, 20(3), 382-402.

Adni, annisa B., Susilo, H., \& Prasetya, A. (2014). Audit Manajemen pada Fungsi Sumber Daya Manusia ( Studi pada Fungsi Pengembangan Organisasi , Rekrutmen-Seleksi-Orientasi ,. Jurnal Administrasi Bisnis, Vol.13(No.1), 1-10.

Agustia, D. (2010). Pelaporan Biaya Lingkungan Sebagai Alat Bantu Bagi Pengambilan Keputusan Yang Berkaitan Dengan Pengelolaan Lingkungan. AKRUAL: Jurnal Akuntansi, 1(2), 190. https://doi.org/10.26740/jaj.v1n2.p190-214

Ahmad, A. (2012). Envirowment Accounting and Reporting Practises: Significance and Issues: A Case from Bangladeshi Companies. Global Journal of Management and Business Research, 12(14), 118-127.

Bangun, R. N., \& Sunarni, C. W. (2014). Pelaporan Biaya Lingkungan dan Penilaian Kinerja Lingkungan ( Studi kasus PT Tanjungenim Lestarsi Pulp and Paper ). Jurnal Ilmiah Akuntansi, 66(03), 37-39.

Bapedal. Baku Mutu Limbah Cair Bagi Kegiatan Rumah Sakit, Keputusan Menteri Negara Lingkungan Hidup No. Kep-58/MENLH/12/1995 (2004).

Bastian, I. (2008). Akuntansi Kesehatan. (S. Saat \& W. Hardani, Eds.) (1st ed.). Jakarta: Erlangga.

Burhany, D. I. (2014). Pengaruh Implementasi Akuntansi Lingkungan Terhadap Kinerja Lingkungan dan Pengungkapan Informasi Lingkungan (Studi pada Perusahaan Pertambahan Umum yang Mnegikuti PROKER Periode 2008-2009). In Proceedings SNEB (pp. $1-8)$.

Busriyanti. (2016). Islam dan lingkungan hidup studi terhadapa fiqh al-bi'ah sebagai solusi pelestarian ekosistem dalam perspektif Maqashid Syariah. Jurnal Fenomena, 15(2), 259-280.

Cahyani, I. (2014). Teori dan Aplikasi Maqashid Al-Syariah. Jurnal AlQadāu, l(2).

Debora, M. F., \& Ismail, M. (2013). Implikasi Akuntansi Lingkungan Serta Etika Bisnis Sebagai Faktor Pendukung Keberlangsungan Perusahaan di Indonesia. Jurnal Akuntansiku, 1(1), 1-15.

Dedi, S. (2016). Perluasan Teori Maqashid Al-Syari' ah: Kaji Ulang Wacana Hifdz Al-'Ummah A.Djuzuli. Jurnal Hukum Islam, 1(1), 4561.

Ditjen PPM dan PLP. (2002). Program Sanitasi Rumah Sakit di Indonesia. 
Jakarta: Departemen Kesehatan RI.

Fitri, N. (2014). Analisis Penerapan Akuntansi Lingkungan terhadap Pengelolaan Limbah. Artikel Mahasiswa, 1-7.

Hamidi, M. L., \& Worthington, A. C. (2018). Perbankan Sosial Islam: Langkah ke Depan. Jurnal Ekonomi Malaysia, 52(1), 179-190.

Ikhsan, A. (2008). Pengenalan Akuntansi Lingkungan (1st ed.). Yogyakarta: Graha Ilmu.

Irawan, A. (2016). Pencemaran lingkungan (Studi pada PG Gempolkrep Mojokerto Periode 2013-2015). Jurnal Admininstrasi Bisnis, 40(1), 97104.

Islamey, F. E. (2016). Perlakuan Akuntansi Lingkungan Terhadap Pengelolaan Limbah pada Rumah Sakit Paru Jember. Jurnal Fakultas Ekonomi Universitas Muhammadiyah Jember, 1(7), 1-20.

Kusuma, A., Asmeri, R., \& Begawati, N. (2010). Limbah Dan Tanggung Jawab Sosial Pada Rumah Sakit Stroke Nasional Bukittinggi. Jurnal Angga, 4.0(1), 1-15.

Kusumawati, T., \& Sudarsono. (2015). Perlakuan Akuntansi Atas Pengelolaan Limbah Pada Rumah Sakit Umum Daerah Dr. R. Koesma Tuban. In Artikel Ilmiah Mahasiswa (pp. 1-6).

Lako, A. (2004). Kepemimpinan dan Kinerja Organisasi: Isu, Teori, dan Solusi (Cetakan Pe, Vol. 8). Yogyakarta: penerbit andi.

Lindawati, A. S. L., \& Puspita, M. E. (2015). Corporate Social Responsibility: Implikasi Stakeholder dan Legitimacy Gap dalam Peningkatan Kinerja Perusahaan. Jurnal Akuntansi Multiparadigma, 01(04), 157-174. https://doi.org/10.18202/jamal.2015.04.6013

Martusa, R. (2009). Peranan Environmental Accounting terhadap Global Warming. Jurnal Akuntansi, 1(2), 164-179.

Musyarofah, S. (2013). Analisis Penerapan Green Accounting Di Kota Semarang. Accounting Analysis Journal, 2(3), 352-359. https://doi.org/10.15294/aaj.v2i3.2855

Noviani, \& Aminah. (2014). Analisis Penerapan Akuntansi Lingkungan di Rumah Sakit Mardi Waluyo Metro. Jurnal Akuntansi Dan Keuangan, 5(2), 1-16.

Piranti, K. (2019). Analisis Kepuasan Pasien Di Instalasi Rawat Inap Rumah Sakit Umum (Rsu) Haji Surabaya Berdasarkan Dimensi Mutu Dabholkar. The Indonesian Journal of Public Health. https://doi.org/10.20473/ijph.v14i2.2019.161-174

Pranata, M. W., \& Laela, S. F. (2020). Board Characteristic, Good Corporate Governance and Maqâshid Performance in Islamic Banking. Journal of Islamic Monetary Economics and ..., 6(2), 1-24. 
Pujiati. (2004). Upaya Peningkatan Pengelolaan Limbah Padat Berdasarkan Hasil Evaluasi Penerapan Protap: Studi Kasus Pengelolaan Limbah Padat Rumah Sakit Dr. Iskak Kabupaten Tulungagung). Jurnal Thesis UNAIR, 2(4).

RSU Haji Surabaya. (2003). Menebar Senyum dan Salam dalam Pelayanan. Surabaya: Rumah Sakit Umum Haji Surabaya.

Said. (2008). Pengolahan Air Limbah Dengan Biakan Tersuspensi.

Sakdiyah, H. (2017). Analisis Penerapan Environmental Managemental Accounting (EMA) Pada RSUD DR. H. Slamet Martodjirjo Pamekasan. Jural Performance Bisnis Dan Akuntansi, 5(1), 1-18.

Sambharakreshna, Y. (2009). Akuntansi Lingkungan Dan Akuntansi Manajemen Lingkungan: Suatu Komponen Dasar Strategi Bisnis. Jurnal Infestasi, 5(1), 1-21.

Sari, M., Faridah, \& Setiawan, L. (2017). Aanalisis penerapan akuntansi lingkungan pada rumah sakit umu daerah daya Makassar. Jurnal Riset Edisi XII, 3(001), 42-54.

Setya, E. R. (2017). Farmasi Rumah Sakit. Sleman: CV Budi Utama.

Suaryana, A. (2011). Implementasi Akuntansi Sosial dan Lingkungan di Indonesia. Jurnal Ilmiah Akuntansi Dan Bisnis, 1-26.

Sulistiadi, W., \& Rahayu, S. (2016). Potensi Penerapan Maqashid Syariah Dalam Rumah Sakit Syariah Di Indonesia. Batusangkar International Conference 1: Integration and Interconnection of Sciences "The Reflection of Islam Kaffah, ” 2(10), 683-690.

Sulistyorini. (2005). Pengelolaan Sampah Dengan Menjadikannya Kompos. Jurnal Kesehatan Lingkungan, 2(1), 77-84.

Sunawi. (2012). Konsep Pelayanan Islami di Rumah Sakit; Tinjauan Aplikasi di Rumah Sakit Islam Surakarta.

Suparmadja, A. (2015). Kinerja IPAL Rumah Sakit Menggunakan Metode Fault Tree Analysis (FTA). Jurnal Reposiitory ITStory ITS, 4(1).

Triana, N., \& Keman, S. (2006). Evaluasi Pengelolaan Sampah Padat di Rumah Sakit Umum Haji Surabaya. Jurnal Kesehatan Lingkungan, 3(1), 21-34.

Trisnawati, R. (2014). Pengaruh Ukuran Perusahaan, Profitabilitas, Leverage, Ukuran Dewan Komisaris dan Kepemilikan Manajerial Terhadap Pengungkapan Corporate Social Responsibility (CSR) Industri Perbankan di Indonesia. Seminar Nasional Dan Call For Paper, 6(October), 27-32.

Utama, A. A. G. S. (2016). Akuntansi lingkungan sebagai suatu sistem informasi: Studi pada Perusahaan gas Negara (PGN). Jurnal Bisnis Dan Manajemen, 6(4), 89-100. https://doi.org/10.15408/ess.v6i1.3123 
Widialoka, M. (2017). Penerapan akuntansi lingkungan pada pengelolaan limbah rumah sakit jember klinik. Repository Universitas Muhammadiyah Jember, 3(03), 1-13.

Windasari, D., \& Herumurti, W. (2010). Pengelolaan Limbah B3 Medis Rumah Sakit Khusus di Surabaya Pusat dan Selatan. Jurnal Teknik Lingkungan ITS, 2(340), 1-11. 